\title{
Arm amputation secondary to squamous cell carcinoma: exotic expeditions leading to a delayed diagnosis?
}

\author{
Kevin McGarry, Michael McBride, Harry Lewis
}

Department of Plastic Surgery, South Eastern Health and Social Care Trust, Dundonald, UK

\section{Correspondence to Mr. Kevin McGarry, kmcgarry10@qub.ac.uk}

Accepted 21 December 2017

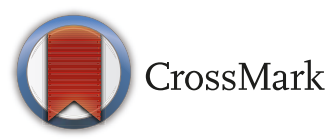

To cite: McGarry K, McBride M, Lewis H. BMJ Case Rep Published Online First: [please include Day Month Year]. doi:10.1136/ bcr-2017-223880

\section{DESCRIPTION}

Despite squamous cell carcinoma being one of the most common skin cancers in the $\mathrm{UK},{ }^{1}$ atypical presentations can lead to delayed diagnosis and management. Here, we present a 67-year-old man who had spent a considerable period of his adult life in the Congo as a gold prospector, referred to us by the dermatology team. The man reported an insect bite that had developed into a chronic ulcer of his left forearm sometime in the early 1990s. The ulcer had been managed conservatively for over 15 years in primary care without ever completely resolving; however, over the past year, it had rapidly developed into a large fungating mass encompassing the majority of the left forearm (figure 1). The wound was discharging pus and had an offensive odour that the patient reported was requiring daily dressings in the community to manage. The patient reported that over the past year of rapid growth he had felt increasingly unwell with frequent temperatures, nausea and lack of appetite.

He underwent full serological viral screening and multiple blood cultures that were all negative. Repeated core biopsy by the dermatology team failed to produce a histological diagnosis. Chronic inflammatory cells and epithelial sinus tracts of unknown significance were reported. Microbiology reported the presence of Pasteurella canis that cultured from within the lesion; however, two courses of intravenous antibiotics provided no benefit.

We proceeded to excision biopsy of the whole lesion and intraoperatively discovered an infiltrative mass that was aggressively osteodestructive of the distal radius, however sparing of all soft tissues, including tendons and neurovascular bundles (figure 2). Histology of this block section revealed

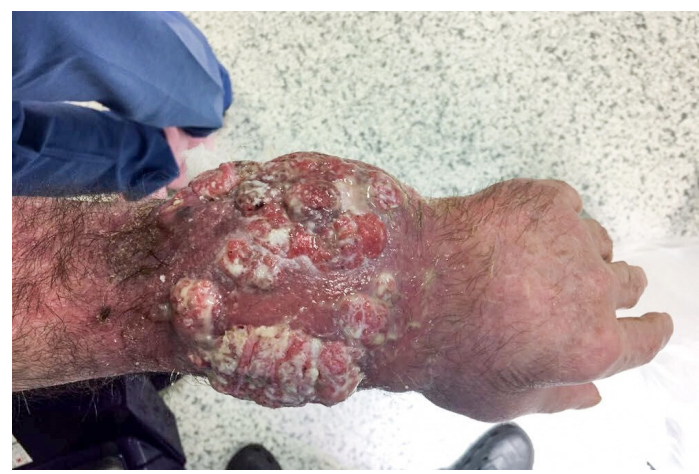

Figure 1 Fungating forearm lesion.

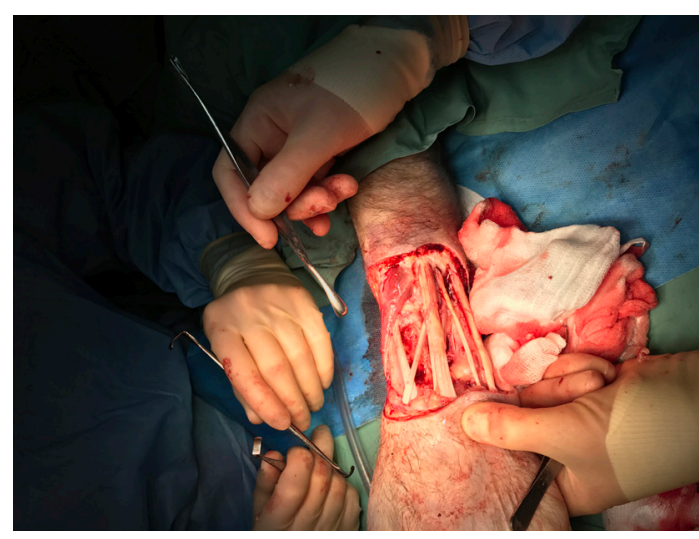

Figure 2 Intraoperative image post excision highlighting unusual soft tissue sparing of cancer.

\section{Learning points}

- For any locally destructive skin lesions not responding to topical therapies, a diagnosis of skin cancer must be excluded.

- Although core biopsy of a lesion usually is sufficient to produce a diagnosis on occasion, total excision may be required.

- A history of foreign travel or atypical infection may delay diagnosis in what otherwise would be a presumed malignant process.

a massive poorly differentiated squamous cell carcinoma with bony involvement.

Following Multi-Disciplinary-Team (MDT) discussion, we proceeded to amputation of the arm at the level of the elbow to achieve clear margins. Additionally, an palpable ipsilateral cervical node was removed intraoperatively for histological processing, as we were concerned this may have been an indication of lymphatic spread. Oncology follow-up is ongoing; however, at present (6 months post amputation), there is no evidence of local or regional recurrence.

Squamous cell carcinoma in the presence of chronic inflammation is a rare but recognised phenomenon in the form of a Marjolin's ulcer. We believe this to be the first described case of a Marjolin's ulcer secondary to an insect bite. $^{2}$ 
$\mathrm{MMcB}$ also contributed to this draft and was responsible for critical revision. HL was responsible for conceiving the idea of the study and additionally gaining the images included. All authors had final approval of this version to be published and agree to be accountable for all aspects of the work, ensuring that questions related to the accuracy or integrity of any part of the work are appropriately investigated and resolved.

Competing interests None declared.

Patient consent Obtained.

Provenance and peer review Not commissioned; externally peer reviewed.
(C) BMJ Publishing Group Ltd (unless otherwise stated in the text of the article) 2018. All rights reserved. No commercial use is permitted unless otherwise expressly granted.

\section{REFERENCES}

1 accessed 8 Dec 17 http://www.ncin.org.uk/publications/data_briefings/non_ melanoma_skin_cancer_in_england_scotland_northern_ireland_and_ireland\#

2 Sadegh Fazeli M, Lebaschi AH, Hajirostam M, et al. Marjolin's ulcer: clinical and pathologic features of 83 cases and review of literature. Med I Islam Repub Iran 2013;27:215-24.

Copyright 2017 BMJ Publishing Group. All rights reserved. For permission to reuse any of this content visit

http://group.bmj.com/group/rights-licensing/permissions.

BMJ Case Report Fellows may re-use this article for personal use and teaching without any further permission.

Become a Fellow of BMJ Case Reports today and you can:

- Submit as many cases as you like

- Enjoy fast sympathetic peer review and rapid publication of accepted articles

- Access all the published articles

- Re-use any of the published material for personal use and teaching without further permission

For information on Institutional Fellowships contact consortiasales@bmjgroup.com

Visit casereports.bmj.com for more articles like this and to become a Fellow 